UDK $577.1: 61$

ISSN 1452-8258

J Med Biochem 39: 54-59, 2020

\title{
PLATELET GLUTAMATE DEHYDROGENASE ACTIVITY AND EFFICACY OF ANTIPSYCHOTIC THERAPY IN PATIENTS WITH SCHIZOPHRENIA
}

\section{AKTIVNOST TROMBOCITNE GLUTAMAT DEHIDROGENAZE I EFIKASNOST ANTIPSIHOTIČNE TERAPIJE U PACIJENATA SA SHIZOFRENIJOM}

\author{
Olga K. Savushkina1, Elena B. Tereshkina1, Tatiana A. Prokhorova1, Irina S. Boksha1,2, \\ Denis S. Burminskii ${ }^{1}$, Elena A. Vorobyeva, Margarita A. Morozova1, Gulnur Sh. Burbaeva ${ }^{1}$ \\ ${ }^{1}$ Laboratory of Neurochemistry, Mental Health Research Centre, \\ Federal State Budgetary Scientific Institution, Moscow, Russia \\ ${ }^{2}$ Laboratory of Biologically Active Nanostructures, Gamaleya Center of Epidemiology and Microbiology, \\ Ministry of Health of the Russian Federation, Moscow, Russia
}

\begin{abstract}
Summary
Background: Evaluation of possible relationship between platelet glutamate dehydrogenase (GDH) activity and mental state of schizophrenia patients after antipsychotic pharmacotherapy.

Methods: Patients $(n=50)$ with chronic paranoid schizophrenia (F20.0) initially in acute psychotic state were examined before and after a treatment course with antipsychotics. When assessing the patients' states using PANSS, the "responder " category was attributed to those patients who had not less than 30\% reduction in the score for the corresponding PANSS "subscale«. The control group ( $n=$ 48) was age- and gender-matched with the patient group. Platelet glutamate dehydrogenase $(\mathrm{GDH})$ activity was measured in patients twice, before and after the treatment course, and once in controls.

Results: Significantly reduced GDH activity was found in patients compared with controls. The patient group was divided into two subgroups according to median GDH activity at baseline: above and below the median GDH, subgroup 1 and subgroup 2, respectively. GDH activity significantly increased from its level at baseline after antipsychotic treatment in subgroup 2. Distribution of non-
\end{abstract}

Address for correspondence:

Irina Sergeevna Boksha, PhD, Dr. Natural Sci., Chief Scientific Researcher, Laboratory of Neurochemistry, Mental Health Research Centre, Laboratory of Biologically Active Nanostructures, Gamaleya Center of Epidemiology and Microbiology, Ministry of Health of the Russian Federation, Moscow, Russia

e-mail: boksha_irina@mail.ru, neurochem06@mail.ru, 8(495)109-03-93, ad. 3802, Russia, Moscow, 117152, Zagorodnoe sh., 2, bldg. 16, mob. 8-903-586-98-20. ORCID ID 0000-0003-1369-8658

\section{Kratak sadržaj}

Uvod: Proučavan je mogući odnos između aktivnosti trombocitne glutamat dehodrogenaze (GDH) i mentalnog stanja pacijenata sa shizofrenijom nakon antipsihotične terapije.

Metode: Ispitivani su pacijenti $(n=50)$ sa hroničnom paranoidnom shizofrenijom (F20.0) inicijalno u akutnom psihotičnom stanju pre i nakon tretmana sa antipsihoticima. Kada je procenjivano stanje pacijenata primenom PANSS, "resoponder« kategorija je odgovarala onima koji su imali manje od $30 \%$ smanjenja u odnosu na odgovarajuću PANSS »subskalu«. Kontrolnu grupu činilo je $(n=48)$ osoba sličnog pola i starosti. Aktivnost trombocitne glutamat dehidrogenaze (GDH) merena je kod pacijenata dva puta, pre i posle tretmana i jedanput kod kontrola.

Rezultati: Značajno umanjena aktivnost GDH nađena kod pacijenata upoređena je sa vrednošću kod kontrole grupe. Grupa pacijenata podeljena je u dve podgrupe prema srednjoj vrednosti GDH, kod niske aktivnosti kao i iznad i ispod srednje MDH vrednosti kod podgrupe 1 i podrupe 2 . Aktivnost GDH je bila značajno ispod nivoa osnovne vrednosti nakon primene antipsihotične terapije kod podgrupe 2. Distribucija nonrispondera/rispondera nakon antiopsihotične terapije (prema PANSS skorivima) značajno se

List of abbreviations: GDH, glutamate dehydrogenase; PANSS, Positive and Negative Syndrome Scale; NMDA, N-methyl-Daspartate 
responders / responders to antipsychotic treatment (by PANSS scores) was significantly uneven among subgroups 1 and 2 . In subgroup 1, GDH activity levels significantly correlated with PANSS scores after the treatment course.

Conclusions: Baseline platelet GDH activity might serve as a predictor of antipsychotic therapy efficacy in schizophrenia patients.

Keywords: glutamate dehydrogenase, platelets, schizophrenia

\section{Introduction}

Impairment of glutamatergic system regulation contributes to the development of psychosis in schizophrenia (1-3). Glutamate concentration and the activity and concentration of glutamate receptors and transporters are altered in the brain of patients with schizophrenia in comparison with mentally healthy persons; besides, strong antagonists of NMDA glutamate receptors induce psychotomimetic effects. These facts serve a basis for the "glutamate hypothesis « of schizophrenia pathogenesis that is prominent today (4). Glutamate neurotransmitter signal transduction depends on amounts and activity of glutamate receptors and transporters, as well as on activity of glutamate converting enzymes. Glutamate concentration in tripartite synapses is determined by equilibrium between its transport, binding by specific receptors, and metabolism by neuronal and glial enzymes, and the concentration can change due to impairment of glutamate metabolism leading to neurological or mental pathologies, including psychoses (5-7). As a result of investigations of human autopsy brain, characteristic features of glutamate metabolism in schizophrenia have been revealed in comparison with mentally healthy individuals. These features consist in changing both the concentration and intracellular localization of key glutamate metabolizing enzymes such as glutamine synthetase, glutamine synthetaselike protein, glutamate dehydrogenase isoenzymes $(\mathrm{GDH})$, and regulatory links that control the ratio of these enzymes (8). Neurochemical studies of the brain are important for understanding the pathogenesis of schizophrenia, but the search for biochemical changes in the blood of schizophrenic patients is relevant and important in revealing biomarkers helping to choose the right antipsychotic therapy and predict its efficacy (9). There is a need for an inexpensive and reliable pathogenesis-related biomarker for prediction of antipsychotic therapy efficacy in patients with schizophrenia. From this point of view, blood platelets deserve special attention because they possess glutamate system components such as glutamate receptors, transporters (glutamate-dependent ion channels) (10), and some glutamate metabolizing enzymes $(11,12)$.

The key glutamate metabolizing enzyme, glutamate dehydrogenase $(\mathrm{GDH}, \mathrm{EC}$ 1.4.1.3), catalyzes the reaction: razlikovala između podgrupa 1 i 2 . U podgrupi 1 aktivnost GDH značajno je bila u korelaciji sa PANSS skorovima nakon primene terapije.

Zaključak: Osnovna aktivnost trombocitne GDH može da posluži kao prediktor efikasnosti antipsihotične terapije kod pacijenata sa shizofrenijom.

Ključne reči: glutamat dehidrogenaza, trombociti, shizofrenija

$\alpha$-Ketoglutarate $+\mathrm{NH}_{4}^{+}+\mathrm{NAD}(\mathrm{P}) \mathrm{H} \leftrightarrow \mathrm{L}-\mathrm{Glu}+$ $\mathrm{NAD}(\mathrm{P})+\mathrm{H}_{2} \mathrm{O}$

Three isoforms of GDH (GDHI, GDHII, and GDHIII) have been described in the human brain, differing in their strength of association with the cell membrane (12-15). Using antibodies to the human brain $\mathrm{GDH}$ isoforms, two isoenzymes of $\mathrm{GDH}$, similar to GDHI and GDHII, are found in extracts of human platelets, whereas the amount of membrane-associated GDHIII isoform is below the threshold of immunoblotting detection (11). The presence of GDH in platelets is confirmed not only by immunoblotting, but also by the presence of its enzymatic activity (16, 17).

In this study, we evaluated the relationship between the activity of platelet GDH and the efficacy of antipsychotic pharmacotherapy in a group of patients with chronic acute schizophrenia.

\section{Materials and Methods}

\section{Participants}

A group of patients with paranoid schizophrenia (F20.0 according to ICD-10) with chronic course of the disease, all inpatients due to their illness $(n=50$ : 47 men and 3 women aged $25-56$ years, median 34 years), was examined in initially acute psychotic state (hallucinatory paranoid or paranoid syndrome), before and after a treatment course with typical and atypical antipsychotics. A total of 50 patients entered the study, and for 45 patients the study was completed. Exclusion criteria were organic central nervous system diseases and acute and chronic somatic diseases.

Informed consent was obtained from all the participants of the study, the study was performed in conformance with the Declaration of Helsinki ethical guidelines, and ethical approval for the study was obtained from the Ethics Committee of the Mental Health Research Centre (Protocol N343, 14.04.2017). The patients were assessed twice by the attending psychiatrist, before and after the treatment course, using the Positive and Negative Syndrome Scale (PANSS) (18). In accordance with the peculiarities of the mental state of each patient, psychopharma- 
Table I Patient Demography and Clinical Data.

\begin{tabular}{|c|c|c|}
\hline Gender & \multicolumn{2}{|c|}{$47 \mathrm{~m} / 3 f$} \\
\hline $\begin{array}{l}\text { Education: secondary/ } \\
\text { secondary special/ } \\
\text { incomplete higher/higher } \\
\text { (number of patients) }\end{array}$ & \multicolumn{2}{|c|}{$14 / 17 / 9$ / 10} \\
\hline Hereditary burden $(+/-)$ & \multicolumn{2}{|c|}{$11 / 39$} \\
\hline $\begin{array}{l}\text { Predominant } \\
\text { psychopathology: delusional/ } \\
\text { hallucinatory/disorganization } \\
\text { (number of patients) }\end{array}$ & \multicolumn{2}{|c|}{$21 / 21 / 8$} \\
\hline $\begin{array}{l}\text { Hospitalizations: } 1 / 2 / 3 \\
\text { (number of patients) }\end{array}$ & \multicolumn{2}{|c|}{$5 / 8 / 37$} \\
\hline \multirow{2}{*}{$\begin{array}{l}\text { Antipsychotic therapy: } \\
\text { atypical/typical/mixed } \\
\text { (number of patients) }\end{array}$} & \multicolumn{2}{|c|}{$19 / 19 / 12$} \\
\hline & $\begin{array}{l}\text { Median; } \\
\text { minimum } \\
\text { - maximum }\end{array}$ & $\begin{array}{l}25-, 75 \% \\
- \text { quartiles }\end{array}$ \\
\hline Age (years) & $34 ; 20-56$ & $28 ; 42$ \\
\hline Disease duration (months) & $96 ; 2-420$ & $48 ; 240$ \\
\hline Age of manifestation (years) & $25 ; 17-42$ & $19 ; 28$ \\
\hline PANSS positive at baseline & $23 ; 10-35$ & $21 ; 28$ \\
\hline PANSS negative at baseline & $26 ; 12-39$ & $21 ; 29$ \\
\hline PANSS psychotic at baseline & $47 ; 25-71$ & $43 ; 53$ \\
\hline PANSS total at baseline & $96 ; 58-141$ & $89 ; 106$ \\
\hline
\end{tabular}

The control group $(n=48)$ consisted of 45 men and 3 women aged $21-59$ years (median 38 years). Exclusion criteria were the same as for the patient group.

cotherapy individually selected by clinicians was carried out using typical or atypical antipsychotics. The end of the treatment course was determined as improvement in the patient's condition sufficient for discharge from the hospital (about two months after the initiation of the therapy).

When assessing patients' state using PANSS, "responder" category for each PANSS subscale (PANSSpositive subscale, PANSSnegative subscale, and PANSS subscale of general psychopathology) was assigned to those patients who had not less than $30 \%$ reduction of the corresponding PANSS subscale score. Table I contains data on the patients.

\section{Blood sampling}

Blood samples were collected after overnight fasting into evacuated tubes containing anticoagulant agent (3.2\% Na-citrate buffer).

Each blood sample was treated individually within 2 hours after blood collection. Initially, the whole blood was centrifuged for $15 \mathrm{~min}$ at $200 \mathrm{~g}$ and $20^{\circ} \mathrm{C}$. The supernatant (platelet-rich plasma) was used for the subsequent isolation of platelets.

The platelet-rich plasma was centrifuged for 20 $\min$ at $2000 \mathrm{~g}$ at $4{ }^{\circ} \mathrm{C}$. The precipitate was resuspended in $0.105 \mathrm{~mol} / \mathrm{L} \mathrm{Na-citrate}$ buffer with 0.105 $\mathrm{mol} / \mathrm{L}$ glucose $(\mathrm{pH} 5.7)$ and centrifuged again for 20 $\mathrm{min}$ at $2000 \mathrm{~g}$ at $4{ }^{\circ} \mathrm{C}$. The platelet precipitate was resuspended in $0.05 \mathrm{~mol} / \mathrm{L}$ Tris- $\mathrm{HCl}$ buffer, $\mathrm{pH}$ 7.0, with $50 \%$ glycerol, and stored at $-20{ }^{\circ} \mathrm{C}$.

Immediately before determining the activity of $\mathrm{GDH}, 50 \mathrm{mmol} / \mathrm{L}$ K-phosphate buffer $\mathrm{pH} 7.4$ containing dodecyl- $\beta$-D-maltoside was added to the platelet sample to final concentration of $1 \%$. Lysis was carried out for $10 \mathrm{~min}$ at $25{ }^{\circ} \mathrm{C}$, then the samples were centrifuged for $10 \mathrm{~min}$ at $4000 \mathrm{~g}$ at $4{ }^{\circ} \mathrm{C}$. The resulting supernatant was diluted 5 -fold in 50 mmol/L K-phosphate buffer, pH 7.4 (16).

\section{GDH activity measurement}

The activity of GDH was determined by a spectrophotometric method (19) with modifications (17). The sample volume added to $400 \mu \mathrm{L}$ of the reaction mixture was $125 \mu \mathrm{L}$. The reaction mixture composition was $0.1 \mathrm{mmol} / \mathrm{L} \mathrm{NADH}, 0.1 \mathrm{~mol} / \mathrm{L} \mathrm{NH}_{4} \mathrm{Cl}, 10$ $\mathrm{mmol} / \mathrm{L} \alpha$-ketoglutarate, $1 \mathrm{mmol} / \mathrm{L}$ ADP, and 2.6 $\mathrm{mmol} / \mathrm{L}$ EDTA in $0.01 \mathrm{~mol} / \mathrm{L}$ Tris- $\mathrm{HCl} \mathrm{pH} 8.0$ buffer. The measurement of the rate of reaction (1), in this case directed to the right, is based on the loss of absorption of NADH recorded by spectrophotometry at $340 \mathrm{~nm}$ for $3 \mathrm{~min}$. To calculate the enzymatic activity, the value of the molar extinction coefficient of

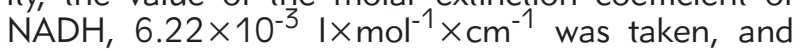
the specific activity of GDH per $1 \mathrm{mg}$ of protein is given in Figures 1 and 2.

Protein concentration was determined by the Lowry spectrophotometric method using a Bio-Rad DC Protein Assay Kit (USA) in accordance with the protocol and using bovine serum albumin (SigmaAldrich) as a protein standard for calibration.

\section{Statistical analysis}

The significance of differences between experimental groups was determined using »nonparametric analysis«. The significance of differences, changes in the parameters, and connections between them were assessed using the Mann-Whitney U-test, Chi-square test with Yates correction, Spearman correlation coefficients determination, and the Wilcoxon matched pair test. Differences and correlations were considered significant at $\mathrm{p}<0.05$. 


\section{Results}

The schizophrenia-patient and control groups were matched in age and gender, allowing betweengroup comparison of GDH activity. Significantly reduced GDH activity was found in the patient group both before and after the treatment course compared with the control group (Mann-Whitney U-test, $\mathrm{p}<0.01$ and $\mathrm{p}<0.04$, respectively), thus we reproduced our previous data (17).

The results of GDH activity determination for the schizophrenia patients before (baseline) and after the treatment course are shown in Figure 1.

When regarding the individual values of $\mathrm{GDH}$ activity in the patient group before the treatment course, substantial variation in values was noted. Therefore, this group of patients was divided into two subgroups by the median of the baseline (initial) GDH activity for further statistical analysis. The Wilcoxon matched-pair test showed that the GDH activity significantly increased after the treatment ( $p=0.002)$ in the subgroup with the activity of baseline GDH below the median. Figure 2 shows obvious dynamics of GDH activity during the treatment in this subgroup: the majority (18 patients) demonstrated an increase, and the other 5 showed no change or a decrease in GDH activity, whereas no significant changes in GDH activity were observed after the treatment in the subgroup with the baseline GDH activity above the median.
After the treatment course, significant correlations of GDH activity levels with PANSS negative and PANSS total score were revealed in the subgroup with the baseline GDH activity above the median (Spearman correlation coefficients $\mathrm{R}=0.56, \mathrm{p}=0.007$ and $\mathrm{R}=0.45, \mathrm{p}=0.04$, respectively). Besides, there was a significantly higher number of responders in this subgroup (for instance, by PANSS positive subscale, Chi-square with Yates correction $=9.1, \mathrm{p}=$ 0.001) (Table II).

Table II Distribution of Responders and Non-responders (in Percentages of Total Group) by PANSS between the Subgroups of Patients with Baseline GDH Activity Below and Above the Median.

\begin{tabular}{|l|c|c|c|c|}
\hline \multirow{2}{*}{$\begin{array}{l}\text { PANSS } \\
\text { subscale }\end{array}$} & \multicolumn{2}{|c|}{ Below median GDH } & \multicolumn{2}{c|}{ Above median GDH } \\
\cline { 2 - 5 } & Responders & $\begin{array}{c}\text { Non- } \\
\text { responders }\end{array}$ & Responders & $\begin{array}{c}\text { Non- } \\
\text { responders }\end{array}$ \\
\hline Positive & 29 & 20 & 44 & 7 \\
\hline Negative & 0 & 49 & 9 & 42 \\
\hline $\begin{array}{l}\text { General } \\
\text { psycho- } \\
\text { pathology }\end{array}$ & 7 & 42 & 18 & 33 \\
\hline Total & 11 & 38 & 22 & 29 \\
\hline
\end{tabular}

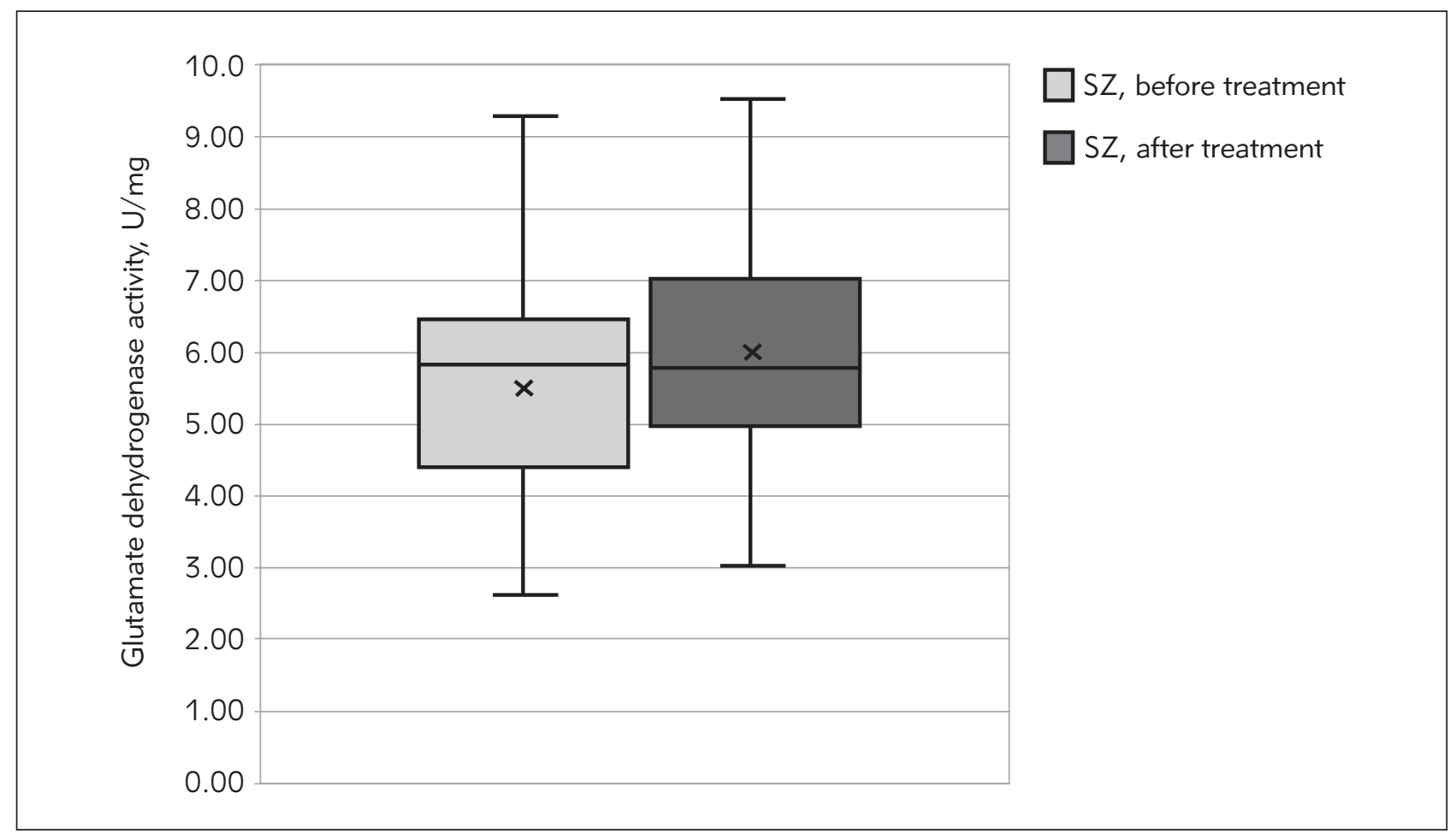

Figure $1 \mathrm{GDH}$ activity in patients with schizophrenia (SZ) before (baseline) and after the treatment course. 


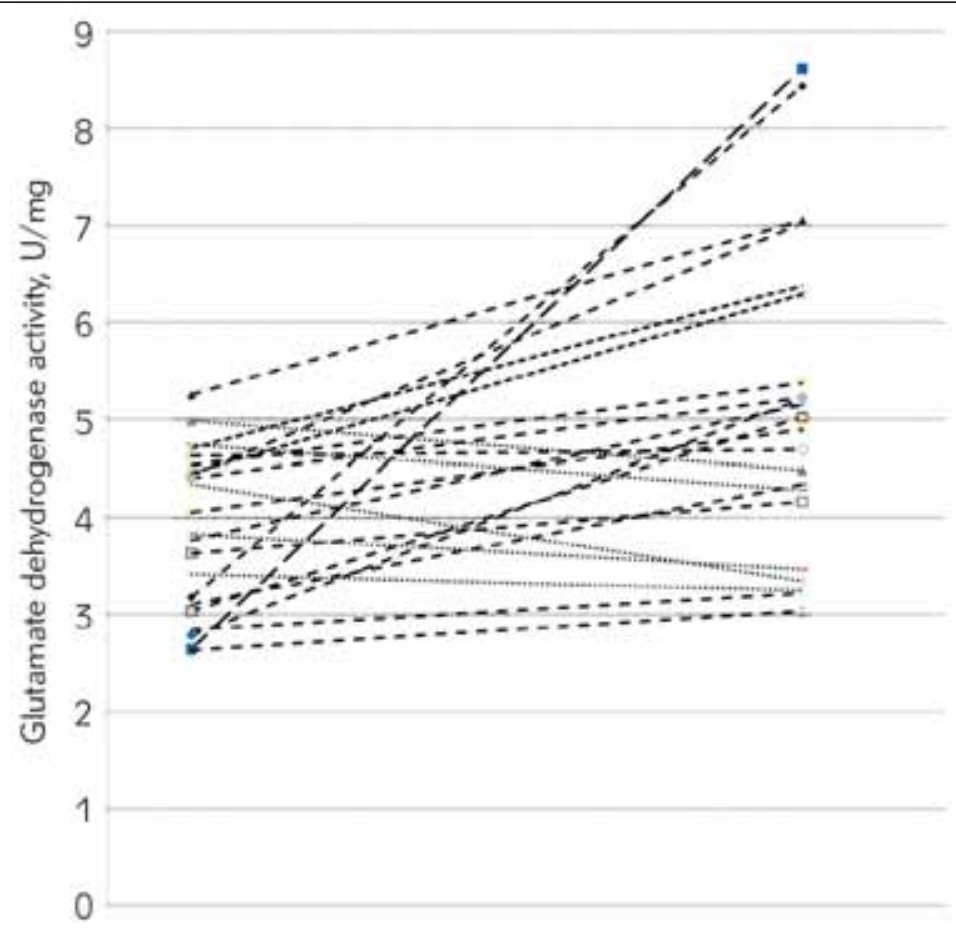

Figure 2 Dynamics of GDH activity for patients with baseline GDH activity below the median.

On the other hand, there was a significantly higher number of non-responders in the subgroup with baseline GDH activity lower than the median. Among these were non-responders by PANSS negative subscale score (Chi-square with Yates correction $=7.5, \mathrm{p}=0.006$ ), by PANSS psychotic (Chi-square with Yates correction $=5.7, \mathrm{p}=0.02$ ), and by PANSS total score (Chi-square with Yates correction $=3.8, \mathrm{p}=0.04)$.

\section{Discussion}

As we indicated in the Introduction, we previously found two GDH forms (similar to GDHI and GDHII) in human platelet extracts $(9,11)$ when the proteins were extracted using detergent (sodium dodecylsulfate, SDS) and the samples boiled with SDS according with the ECL-immunoblotting protocol developed for evaluation of GDHI and GDHII in human brain extracts using the same immunoprobes (i.e. antibodies recognizing human brain $\mathrm{GDHI}$ and GDHII) (8). When estimating GDH amount by immunoblotting, the sum of GDHI and GDHII forms was taken into consideration, and no significant difference was found between the group of patients with paranoid schizophrenia and controls (11).

In the present work, a soft extraction method was employed for GDH enzymatic activity measurement using $\mathrm{n}$-dodecyl $\beta$-D-maltoside, which preserves the enzymatic activity. The GDH activity was found to be significantly higher in the control group than in the patient group. Obviously, SDS and n-dodecyl $\beta$-Dmaltoside may differently extract the GDH forms from platelets, causing different dissociation of the GDH forms particularly from platelet mitochondria.

We would like to emphasize that the method of $\mathrm{GDH}$ enzymatic activity determination is more easily standardized and is not so expensive and time consuming in comparison with ECL-Western immunoblotting, and thus the activity determination is preferable for routine clinical analyses.

Generally, only in the subgroup of patients with baseline GDH activity below the median was the GDH activity significantly increased after the treatment, and a significantly higher number of non-responders to antipsychotic treatment was found in this subgroup.

Correspondingly, a significantly higher number of responders was found in the other subgroup with baseline GDH activity above the median, and significant correlations of GDH activity levels with PANSS negative scores and PANSS total scores were revealed after the treatment in this subgroup.

\section{Conclusion}

Significantly different uneven distribution of responders and non-responders between two subgroups of patients with paranoid schizophrenia (with baseline GDH activity above and below the GDH 
median) indicates that measurement of platelet GDH activity in patients with paranoid schizophrenia before the course of antipsychotic treatment might be useful for individual prediction of the efficacy of antipsychotic pharmacotherapy.

Acknowledgments. We thank Richard H. Lozier for his very useful comments and assistance in work on this manuscript.

\section{References}

1. Egerton A, Stone JM. The glutamate hypothesis of schizophrenia: neuroimaging and drug development. Curr Pharm Biotechnol 2012; 13(8): 1500-12.

2. Egerton A, Fusar-Poli P, Stone JM. Glutamate and psychosis risk. Curr Pharm 2012; 18(4): 466-78.

3. Merritt K, McGuire P, Egerton A. Relationship between Glutamate Dysfunction and Symptoms and Cognitive Function in Psychosis. Front Psychiatry 2013; 4: 151.

4. Howes O, McCutcheon R, Stone J. Glutamate and dopamine in schizophrenia: an update for the 21st century. J Psychopharmacol 2015; 29(2): 97-115.

5. Bernstein H-G, Tausch A, Wagner R, Steiner J, Seeleke P, Walter $M$, et al. Disruption of glutamate-glutamineGABA cycle significantly impacts on suicidal behaviour: survey of the literature and own findings on glutamine synthetase. CNS \& Neurological Disorders - Drug Targets 2013; 12(7): 900-13.

6. Bernstein H-G, Steiner J, Dobrowolny H, Bogerts B, Guest PC. Glial cells as key players in schizophrenia pathology: recent insights and concepts of therapy. Schizophrenia Research 2015; 161(1): 4-18.

7. Plaitakis A, Kalef-Ezra E, Kotzamani D, Zaganas I, Spanaki C. The Glutamate Dehydrogenase Pathway and Its Roles in Cell and Tissue Biology in Health and Disease. Biology (Basel). 2017; 6(1).

8. Boksha IS, Savushkina OK, Tereshkina EB, Prokhorova TA, Mukaetova-Ladinska EB. Enzymes of Glutamate System. In: Parrot S., Denoroy L. (eds) Biochemical Approaches for Glutamatergic Neurotransmission. Neuromethods, 130. New York, NY, Humana Press; 2018: 469-506.

9. Burbaeva GSh, Boksha IS, Kaleda VG, Barkhatova AN, Turishcheva MS, Omel'chenko MA, et al. Glutamine synthetase-like protein, glutamate dehydrogenase, and cytochrome c-oxidase in platelets of patients with the first episode psychosis in the course of treatment. Zh Nevrol Psikhiatr Im S S Korsakova 2011; 111(9): 61-6. [Russ]

10. Kasatkina LA, Borisova TA. Glutamate release from platelets: exocytosis versus glutamate transporter reversal. Int J Biochem Cell Biol 2013; 45(11): 2585-95.

\section{Conflict of interest statement}

The authors state that they have no conflicts of interest regarding the publication of this article.

11. Catak Z, Kocdemir E, Ugur K, Yardim M Sahin İ, Kaya H, Aydin S. A novel biomarker renalase and its relationship with its substrates in schizophrenia. J Med Biochem 2019; 38: 299-305

12. Burbaeva GSh, Turishcheva MS, Vorobyeva EA, Savushkina OK, Tereshkina EB, Boksha IS. Diversity of glutamate dehydrogenase in human brain. Prog Neuropsychopharmacol Biol Psychiatry 2002; 26(3): 427-35.

13. Arslan DF, Karakoyun I, Basok IB, Aksit ZM, Celik E, Dogan K, Duman $C$. The effects of education and training given to phlebotomists for reducing preanalytical errors. J Med Biochem 2018; 37: 172-80.

14. Bunik V, Artiukhov A, Aleshin V, Mkrtchyan G. Multiple forms of glutamate dehydrogenase in animals: structural determinants and physiological implications. Biology (Basel) 2016; 5(4): 53.

15. Plaitakis A, Zaganas I, Spanaki C. Deregulation of glutamate dehydrogenase in human neurologic disorders. J Neurosci Res 2013; 91(8): 1007-17.

16. Gluck MR, Thomas RG, Sivak MA. Unaltered cytochrome oxidase, glutamate dehydrogenase and glutaminase activities in platelets from patients with sporadic amyotrophic lateral sclerosis-a study of potential pathogenetic mechanisms in neurodegenerative diseases. J Neural Transm (Vienna). 2000; 107(12): 1437-47.

17. Prokhorova TA, Boksha IS, Savushkina OK, Tereshkina EB, Vorobyeva EA, Pomytkin AN, et al. Glutamate dehydrogenase activity in platelets of patients with endogenous psychosis. Zh Nevrol Psikhiatr Im S S Korsakova 2016; 116(3): 44-8. [Russ].

18. Kay SR, Fiszbein A, Opler LA. The positive and negative syndrome scale (PANSS) for schizophrenia. Schizophr Bull 1987; 13(2): 261-76.

19. Fahien LA, Wiggert BO, Cohen PP. Crystallization and kinetic properties of glutamate dehydrogenase from frog liver. J Biol Chem 1965; 240: 1083-90. 